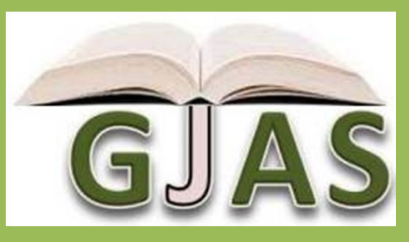

\title{
Comparative Proximate Analysis of Maize and Sorghum Bought from Ogbete Main Market of Enugu State, Nigeria
}

\section{Ape David I ${ }^{\star 1}$, Nwogu Nwanyinnaya $A^{2}$, Uwakwe Ezekiel I Ikedinobi Chinelo $\mathrm{S}^{4}$}

\author{
${ }^{1,2,3,4}$ Materials and Energy Technology Department, Projects Development Institute (PRODA) \\ Emene, Enugu State, Nigeria.
}

Article No.: 101516167

DOI: 10.15580/GJAS.2016.9.101516167

Submitted: 15/10/2016

Accepted: 22/10/2016

Published: 31/10/2016

${ }^{*}$ Corresponding Author

Ape David I

E-mail: apedavid4u@yahoo.com
Maize and sorghum plays an important role in the diet of Africans, it serves as a major source of carbohydrate in both human and livestock diet for release of energy needed for normal body metabolism. In this research white maize and white sorghum (Guinea corn) both of the grass family were analysed for their proximate contents. The maize and sorghum (Guinea corn) were found to be nutritious both contained carbohydrate, protein, fats and oil, crude fibre content and minerals (Ash). In the research carried out it was found that maize contained moisture content of $7.16 \%$, Protein $\mathbf{8 . 7 5} \%$, Fats and oils $2.40 \%$, Crude fibre $\mathbf{2 . 0 4 \%}$, Carbohydrate $\mathbf{7 7 . 4 6} \%$, Ash content was found to be $2.19 \%$. While sorghum had moisture content of $6.36 \%$, Protein $9.10 \%$, Fats and oils $3.10 \%$, Crude fibre $2.86 \%$,

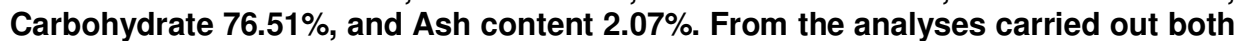
maize and sorghum are good nutritional foods with maize having higher percentage of carbohydrate and sorghum higher percentage of protein.

Keywords:

Maize, Sorghum, Grains,

proximate, Analyses 


\section{INTRODUCTION}

Cereals are the most widely cultivated and consumed crops globally [1]. In Nigeria especially in the northern part of the country, cereals provide a major food resource for man. It is a major source of energy and protein in the diet of many people [1]. Maize estimated annual production is about 5.6million tones and is the most important cereal crop in Nigeria next to sorghum [2]. Maize is a multipurpose crop providing food and fuel for human beings and feeds for livestock, its grains has great nutritional values and can be used as raw materials in manufacturing industries [3]. Maize can be eaten either by boiling, roasting, fried or popped, it can also be used for pap. On the other hand sorghum also known as Guinea corn is a cereal grain that originated in Africa and eaten throughout the world. It is especially valuable in arid terrain because of its resistance to drought [4]. Guinea corn is is a nutrient-rich grain that is often ground into flour to make bread, porridge and pancakes. Including it in our diet offers a number of nutritional and therapeutic benefits [4]. Like other cereal sorghum are predominately starchy making them suitable for brewing industries, about $70-80 \%$ of sorghum starch is amylopectin a branched -chained polymer of glucose and the remaining $20-30 \%$ is amylose[5]. This analyses aims at finding the nutritional relationship between maize and sorghum (Guinea corn) in Enugu state Nigeria.

\section{MATERIALS AND METHODS}

\subsection{Maize and Sorghum}

The samples under study, maize and sorghum (Guinea corn) were bought from Ogbete market from traders, foreign particles were carefully separated from the samples then the samples were pounded into fine particles in a wooden laboratory mortar. Both samples were packaged in polyethylene bags for the analyses. Proximate analysis for both maize and sorghum was done according to standard procedures [6].

\subsection{Determination of Moisture Content}

Procedure: A glass petri-dish was accurately weighed, after which an approximately $1.0 \mathrm{~g}$ of sample was added and reweighed and the weight recorded as (w1). This was kept in a vacuum oven for 1 hour at the $1050 \mathrm{C}$, the dish was removed from the oven, cooled and re-weighed and recorded as (w2). this process was repeated until a constant weight was attained. This process was repeated for all the samples, and the moisture content was calculated in percentage as follows:

$$
\% \text { moisture }=\left(w_{1}-w_{2} / \text { weight of sample used }\right) \times 100
$$

\subsection{Determination of Ash Content}

Procedure:- $1.0 \mathrm{~g}$ of sample was accurately weighed in a platinum crucible and recorded as $\mathrm{w} 1$, this was transferred to muffle furnace at the temperature of $5500^{C}$ for 8 hours until a white ash was obtained. The platinum crucible was removed and place in a dedicator to cool and weighed, the value was recorded as $\mathrm{w}_{2}$, Percentage as was calculated as

$$
\% \text { ash }=\left(w_{1}-w_{2} / \text { weight of sample used }\right) \times 100
$$

This was repeated for all samples.

\subsection{Determination of Fats and Oil}

Cold method of extraction was used to determine fats and oil in all the four samples, $10 \mathrm{~g}$ of samples of accurately weighed into round bottom tom flasks then $50 \mathrm{ml}$ of $\mathrm{n}$-hexane was added to each of the samples and covered for 24 hours for proper extraction of oil after which clean and dried empty beakers were weighed and weights noted. The samples were decanted into the beakers and were heated to dryness and transferred in a desiccator to cool and weighed and new weights taken. Percentage fats were calculated thus;

$\%$ fat or oil $=\left(w_{2}-w_{1} /\right.$ weight of sample used $) \times 100$

\subsection{Crude Fibre Determination}

$2.0 \mathrm{~g}$ of samples were digested in $200 \mathrm{ml}$ of $1.25 \%$ $\mathrm{H}_{2} \mathrm{SO}_{4}$, the mixture was boiled for $30 \mathrm{~min}$. and was filtered and washed with hot water to reduce the acidity, this was tested with $\mathrm{PH}$ paper, the residue was again digested in $200 \mathrm{ml}$ of $1.25 \% \mathrm{NAOH}$. The mixture was heated for 30min. filtered and washed with hot water and dried in an oven, this was transferred to a platinum crucible and weighed $\left(w_{1}\right)$ then heated in a furnace at $5500^{C}$ to as and weighed again $\left(w_{2}\right)$. Percentage crude fibre was calculated as:

$\%$ crude fibre $=\left(w_{1}-w_{2} /\right.$ weight of sample used $) \times 100$

\section{PROTEIN DETERMINATION}

The protein nitrogen in $0.5 \mathrm{~g}$ of dried samples was converted to ammonium sulphate by digestion with concentrated $\mathrm{H}_{2} \mathrm{SO}_{4}$ and in the presence of $\mathrm{Cu}_{2} \mathrm{SO}_{4}$ and $\mathrm{Na}_{2} \mathrm{SO}_{4}$. This was heated and the ammonia involved was steam distilled in $4 \%$ boric acid solution, the nitrogen from ammonia was deduced from the titration of the trapped ammonia with $0.1 \mathrm{~N} \mathrm{H}_{2} \mathrm{SO}_{4}$ with methyl red indicator until a pink colouration was observed indication the end point of titration. Protein was calculated by multiplying the deduced value of nitrogen by a protein constant $6.25 \mathrm{mg}$. 


\subsection{Carbohydrate Determination}

The carbohydrate content of the samples was estimated as the difference obtained after subtracting the values of organic protein, ash content, fat or oil, crude fibre, and moisture content from 100. That is 100- (protein + ash + oil + crude fibre + moisture content).

\section{RESULT AND DISCUSSION}

\begin{tabular}{|l|c|c|}
\hline \multicolumn{2}{|c|}{ Table 1: Proximate analyses result of maize and sorghum grains } \\
\hline Parameters \% & Sample & Sample \\
\hline & Maize & Sorghum \\
\hline Moisture content & 7.16 & 6.36 \\
\hline Protein & 8.75 & 9.10 \\
\hline Fats and oil & 2.40 & 3.10 \\
\hline Crude fibre & 2.40 & 2.86 \\
\hline Ash content & 2.19 & 2.07 \\
\hline Carbohydrate & 77.46 & 76.51 \\
\hline
\end{tabular}

Maize and sorghum (Guinea corn) contains protein, fats and oils, carbohydrate, making it a complete food for both human and livestock [7]. The table shows the proximate analysis result of the maize and sorghum. From the table, the moisture content of maize is $7.16 \%$, and sorghum $6.36 \%$ with maize having a higher moisture content, when compared to the works of [8] which has moisture content for maize from the range of (9.8511.35) and that of [5] with $12 \%$ moisture content for sorghum, it is seen that the references has a higher percentages of moisture content this indicate that the grains under study can be stored for a more longer time since higher moisture content affects shelf life. Also the protein values of maize and sorghum are seen from the table to be $8.75 \%$ and $9.10 \%$ with sorghum having higher percentage of protein, comparing the results with the work of [5] which report protein content of maize and sorghum to be $9.2 \%$ and $10.4 \%$ respectively, it shows closer results and agreed that sorghum has more protein value than maize. The percentage of fats and oil as indicated from the table shows that maize and sorghum has $2.40 \%$ and $3.10 \%$ and sorghum having higher fats and oil percentage than maize, comparing the results with the work of [5], the result shows disagreement as maize has a higher fats value of $4.60 \%$ and sorghum $3.10 \%$ thus percentage fats of sorghum in this analysis corresponds with that of [5], the result also shows closer relationship with the work of [9]. The analysis shows that both maize and sorghum has very low crude fibre of $2.04 \%$ and $2.86 \%$ corresponding to the work of [9] and [5]. Ash contents indicates the level of minerals present in samples [7]. Thus from the table maize and sorghum has ash percentages as $2.19 \%$ and $2.07 \%$ respectively, this result interpret that both maize and sorghum has little minerals in them, comparing the results with the works of [8] and [5], there is close agreement with maize ash content as $1.90 \%--2.32 \%$. The carbohydrate values in maize and sorghum as seen from the table are high with maize $77.46 \%$ and sorghum $76.51 \%$ making them rich-energy foods for both humans and livestock, the result of analysis for both samples correspond to the works of [5], [8] and [9]. 


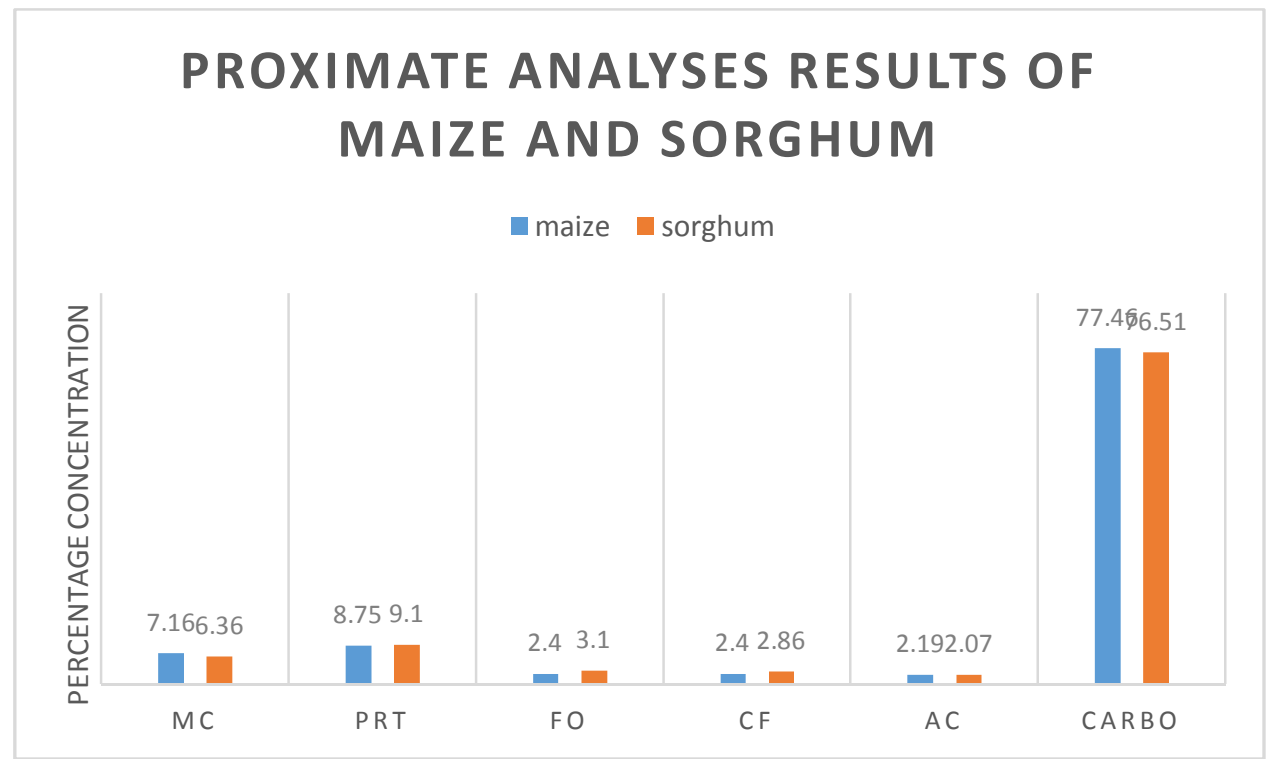

Fig.1: Proximate analyses result of maize and sorghum grains

\section{CONCLUSION}

The result obtained in this analysis show a very close nutritional relationship between maize and sorghum grains as both contain almost similar results of protein, carbohydrate, fats and oil, crude fibre and ash contents, therefore conclusion drawn is that both cereals can be used in place of another for both can serve almost the same nutritional requirement.

\section{REFERENCES}

Sule Enyisi. I. et al (2014) Chemical and nutritional value of maize and maize products obtained from selected markets in Kaduna state Nigeria. African journal of food science and technology vol 5(4) pp 100-104.

Central bank of Nigeria (1992) Annual report of statement of account central bank of Nigeria Lagos. Pp 78.

Afzal Nasir M. et al (2009). Analyses of list plants resistance in some genotype maize against chilo partellus (swin hoe) (pyralidae) : Lepidoptera). Pakistan J. of botany 41:421-428. www.livesrong.com $>$ food and drinks

Deatherage et al (1955) Sorghum and millet in human nutrition. FAO Corporate document repository.

AOAC, official method of analyses. Washington DC. Association of official analytical chemistry, (2000).

Ape et al (2015) Comparative proximate and elemental analyses of four species of Cowper beans seed coat (Vigna ungucuilata) in enugu state, Nigeria. International journal of basic and applied sciences. Vol. (04). Pp. 1-8

Ndukwe et al (2015). Varietal differences in some nutritional journal of academic research and reflection. Vol.(3) No.(5).

Olowalana, Isaac Babatunde (2014). Comparative effects of sprouting on proximate, mineral, composition and functional properties of white and yellow maize. Journal of emerging trends in engineering and applied sciences (JETEAS). 5(7) Pp. 111-115. 